\title{
PENGARUH KEPATUHAN IBU HAMIL TERHADAP KEBERHASILAN PENANGANAN PREEKLAMPSIA DI RUMAH SAKIT SANTA ELISABETH BATAM TAHUN 2014
}

\author{
Oleh: \\ Lilis Sumardiani \\ STIKes Santa Elisabeth Medan \\ E-mail: \\ lilissumardiani@gmail.com
}

\begin{abstract}
Preeclampsia and eclampsia is a pregnancy complication caused directly by pregnancy itself. Successful handling of preeclampsia is determined by the compliance of pregnant women in antenatal care. Pregnant women who do not checkups cause no detection of high risk factors experienced during pregnancy. This is because women do not obey the doctor's orders to carry out checks ANC, diet and adequate rest.This study aims to identify and analyze the effect of maternal adherence (Antenatal Care, diet and rest) to the successful treatment of preeclampsia in Batam Elisabeth Hospital in 2014. The method used is explanatory survey with cross sectional design. The study population is the entire third trimester pregnant women. The research sample that is the entire third trimester pregnant women who checkups at Saint Elisabeth Hospital Batam as many as 47 people. Data were analyzed by multiple logistic regression.The results showed that there was influence compliance in the rest of the successful handling of preeclampsia $(p=0.002)$, whereas compliance in Antenatal care $(p=0.076)$ and compliance in the diet $(p=0.631)$ did not affect the success of treatment of preeclampsia.It is advisable for pregnant women to reduce the routine activities and undertake light activity in an effort to prevent preeclampsia, and it is expected that health professionals, in order to provide counseling for pregnant women who perform health checks, on the benefits of antenatal care, follow the diet and rest in improving maternal health during pregnancy.
\end{abstract}

Keywords: success handling, preeclampsia, pregnancy

\begin{abstract}
ABSTRAK
Preeklampsia dan eklampsia adalah komplikasi kehamilan yang disebabkan langsung oleh kehamilan itu sendiri. Keberhasilan penanganan preeklampsia ditentukan oleh
\end{abstract}


kepatuhan ibu hamil dalam perawatan antenatal. Wanita hamil yang tidak menjalani pemeriksaan tidak mendeteksi faktor-faktor risiko tinggi yang dialami selama kehamilan. Ini karena wanita tidak mematuhi perintah dokter untuk melakukan pemeriksaan ANC, diet dan istirahat yang cukup. Penelitian ini bertujuan untuk mengidentifikasi dan menganalisis pengaruh kepatuhan ibu (Perawatan Antenatal, diet dan istirahat) terhadap keberhasilan pengobatan preeklampsia di Batam Elisabeth Rumah Sakit tahun 2014. Metode yang digunakan adalah survey explanatory dengan desain cross sectional. Populasi penelitian adalah seluruh wanita hamil trimester ketiga. Sampel penelitian yaitu seluruh ibu hamil trimester ketiga yang menjalani pemeriksaan di Rumah Sakit Saint Elisabeth Batam sebanyak 47 orang. Data dianalisis dengan regresi logistik ganda. Hasil penelitian menunjukkan bahwa ada pengaruh kepatuhan dalam sisa keberhasilan penanganan preeklampsia $(\mathrm{p}=0,002)$, sedangkan kepatuhan dalam perawatan antenatal $(\mathrm{p}=0,076)$ dan kepatuhan dalam diet $(\mathrm{p}=0,631)$ tidak mempengaruhi keberhasilan pengobatan preeklampsia. Dianjurkan bagi wanita hamil untuk mengurangi kegiatan rutin dan melakukan aktivitas ringan dalam upaya untuk mencegah preeklampsia, dan diharapkan para profesional kesehatan, untuk memberikan konseling bagi wanita hamil yang melakukan pemeriksaan kesehatan, pada manfaat perawatan antenatal, mengikuti diet dan istirahat dalam meningkatkan kesehatan ibu selama kehamilan.

Kata kunci: penanganan sukses, preeklampsia, kehamilan

\section{PENDAHULUAN}

Preeklampsia dan eklampsia merupakan salah satu komplikasi kehamilan yang disebabkan langsung oleh kehamilan itu sendiri. Preeklampsia adalah timbulnya hipertensi disertai proteinuria akibat kehamilan, setelah umur kehamilan 20 minggu atau segera setelah persalinan.Gejala ini dapat timbul sebelum 20 minggu bila terjadi penyakit trofoblastik (Ammiruddin dkk, 2007). Perdarahan, infeksi, dan eklampsia, merupakan komplikasi yang tidak selalu dapat diramalkan sebelumnya dan mungkin saja terjadi pada ibu hamil yang telah diidentifikasikan normal (Senewe \& Sulistiawati, 2006).
Menurut WHO preeklampsia memengaruhi tujuh sampai sepuluh persen dari seluruh kehamilan di Amerika Serikat (WHO, 2009). Di Inggris kurang dari 10 wanita meninggal akibat preeklampsia setiap tahunnya, dan mempengaruhi maternal yang mengakibatkan kematian, di negara yang kurang berkembang terdapat 50.000 kematian maternal yang disebabkan oleh preeklampsia dan eklampsia (Champman, 2006). Pada sisi lain insiden dari eklampsia pada negara berkembang sekitar 1 kasus per 100 kehamilan sampai 1 kasus per 1700 kehamilan. Pada negara Afrika seperti Afrika Selatan, Mesir, Tanzania dam Etiopia bervariasi sekitar 1,8\% sampai dengan $7,1 \%$. Di Nigeria prevalensinya sekitar 
$2 \%$ sampai dengan $16,7 \%$ (Osungbade dan Ige, 2011).

Keberhasilan penangan preeklampsia pada preeklampsia ringan terjadi penurunan tekanan darah diastolik di bawah $15 \mathrm{mmHg}$ dan tidak ditemukan proteinuria.Tidak ditemukan adanya edema.Meminimalkan gejala-gejala ke arah preeklampsia berat.Pertumbuhan janin, denyut jantung janin dan gerakan janin baik. Pemberian obat antihipertensi, jika tekanan diastoliknya di atas $110 \mathrm{mmHg}$.

Berdasarkan hasil survei awal pada 6 orang ibu hamil yang pernah menderita preeklampsia diketahui seluruhnya ibu masih menganggap kehamilan sebagai hal yang biasa, alamiah dan kodrati. Ada 4 orang ibu yang merasa tidak perlu memeriksakan dirinya secara rutin ke pelayanan kesehatan karena sebelumnya merasa tidak pernah mengalami preeklampsia, 2 orang ibu mempunyai 1 orang anak dan usianya di atas 37 dan 38 tahun dan 2 orang lagi berusia 39 tahun, sedangkan 2 orang ibu hamil lagi ada kurang menyadari pentingnya pemeriksaan kehamilan, ibu belum pernah mempunyai anak dan ibu tersebut tidak patuh mengikuti anjuran peugas kesehatan untuk melakukan ANC. Kedua ibu tersebut hanya 1 kali melakukan pemeriksaan ANC pada trimester pertama. Salah satu berusia 35 tahun dan yang satunya lagi berusia 36 tahun.Ibu hamil yang tidak memeriksakan kehamilannya menyebabkan tidak terdeteksinya faktor-faktor risiko tinggi yang mungkin dialami.Risiko ini baru diketahui pada saat persalinan yang sering kali karena kasusnya sudah terlambat dapat membawa akibat fatal yaitu kematian. Hal ini kemungkinan disebabkan ibu hamil tersebut tidak mematuhi anjuran dokter untuk melakukan pemeriksaan ANC, mengatur pola makan dan istirahat yang cukup.

Berdasarkan latar belakang tersebut di atas, maka ingin dilakukan penelitian tentang "Pengaruh kepatuhan ibu hamil terhadap keberhasilan penanganan preeklampsia di Rumah Sakit Santa Elisabeth Batam tahun 2014.”

\section{METODE PENELITIAN}

Penelitian yang dilakukan
bersifat deskriptif dan rancangan
penelitian yang digunakan ialah
pendeketan Cross Sectional dengan
observasi, pengumpulan data sekaligus
pada suatu saat (point time) yang
dilakukan di Rumah Sakit Elisabeth
Batam tahun 2014. Waktu penelitian
dimulai dari bulan Maret tahun 2014
sampai Agustus 2014 .
Pengumpulan data dilakukan
sendiri oleh peneliti dengan bentuk
kuisioner yang digunakan sebagai
instrument dan terlebih dahulu
memberikan penjelasan singkat
tentang maksud dan tujuan dari lembar
kuisioner (lembar pernyataan). Apabila
responden sudah mengerti, kuisioner
akan diberikan setelah kuisioner diisi
oleh responden kemudian peneliti
mengumpulkan kembali kuisioner dan
apabila ada kurang lengkap peneliti
dapat menyelesaikan saat itu juga.
Analisa data dilakukan dengan
metode penelitian Deskriptif primer,
dengan melihat persentase data yang


telah terkumpul dan disajikan dalam bentuk tabel distribusi frekuensi.

Sampel adalah bagian dari populasi yang merupakan wakil dari populasi itu (Irchan, 2009).Sampel penelitian adalah ibu hamil trimester III yang memeriksakan kehamilannya sejak Bulan Maret sampai Mei 2014 di Rumah Sakit Santa Elisabeth Batam sebanyak 47 orang.

\section{HASIL PENELITIAN}

Tabel 1 Karakteristik Responden di Rumah Sakit Santa ElisabethBatam Tahun 2014

\begin{tabular}{|c|c|c|c|}
\hline No & Umur (tahun) & $\begin{array}{l}\text { Jumlah } \\
\text { (orang) }\end{array}$ & $\begin{array}{c}\text { Persentase } \\
(\%)\end{array}$ \\
\hline 1. & $<20$ tahun & 11 & 23,4 \\
\hline 2. & 20- 35 tahun & 17 & 36,2 \\
\hline 3. & $>35$ tahun & 19 & 40,4 \\
\hline \multicolumn{4}{|c|}{ Usia Kehamilan } \\
\hline 1. & $20-25$ bulan & 2 & 4,3 \\
\hline 2. & 25 - 30 bulan & 18 & 38,3 \\
\hline \multirow[t]{2}{*}{3.} & $>31$ bulan & 27 & 57,4 \\
\hline & Paritas & & \\
\hline 1. & Nulipara & 27 & 57,4 \\
\hline 2. & Primipara & 13 & 27,7 \\
\hline 3. & Secundipara & 5 & 10,6 \\
\hline \multirow[t]{2}{*}{4.} & Multipara & 2 & 4,3 \\
\hline & Pekerjaan & & \\
\hline 1. & Tidak bekerja & 17 & 36,2 \\
\hline 2. & Bekerja & 30 & 63,8 \\
\hline \multicolumn{4}{|c|}{ Pendidikan } \\
\hline 1. & SD & 0 & 0 \\
\hline 2. & SLTP & 26 & 55,3 \\
\hline 3. & SMU & 21 & 44,7 \\
\hline \multicolumn{4}{|c|}{ Pendapatan } \\
\hline 1. & < UMR & 28 & 59,6 \\
\hline 2. & $\geq \mathrm{UMR}$ & 19 & 40,4 \\
\hline
\end{tabular}

Berdasarkan Tabel 1 diketahui responden paling banyak responden berumur diatas 35 tahun yaitu 19 orang $(40,4 \%)$, dan paling sedikit berumur di bawah 20 tahun yaitu 11 orang $(23,4 \%)$. Usia kehamilan paling banyak diatas 31 bulan yaitu 27 orang
$(57,4 \%)$ dan paling sedikit dengan usia kehamilan 20-25 bulan yaitu 2 orang $(4,3 \%)$. Paritas ibu paling banyak yang nulipara (hamil anak pertama) yaitu 27 orang $(57,4 \%)$ dan paling sedikit ibu dengan paritas multipara yaitu 2 orang $(4,3 \%)$. Berdasarkan pekerjaan paling banyak ibu yang bekerja yaitu 30 orang $(63,8 \%)$ dan paling sedikit ibu tidak bekerja yaitu 17 orang $(36,2 \%)$. Pendidikan ibu paling banyak SLTP yaitu 26 orang $(55,3 \%)$ paling sedikit ibu yang berpendidikan SMU yaitu 21 orang $(44,7 \%)$. Ibu paling banyak dengan tingkat pendapatan di bawah UMR yaitu 28 orang $(59,6 \%)$ dan paling sedikit tingkat pendapatan di atas UMR yaitu 19 orang (40,4\%).

\section{Tabel 2 Distribusi Diagnosa Preeklampsia di Sakit Santa Elisabeth Batam Tahun 2014}

\begin{tabular}{|c|c|c|c|}
\hline No & Diagnosa Preeklampsia & $\begin{array}{l}\text { Jumlah } \\
\text { (orang) }\end{array}$ & $\begin{array}{c}\text { Persentase } \\
(\%)\end{array}$ \\
\hline 1. & $\begin{array}{l}\text { Tekanan darah sistolik } \\
<110 \mathrm{mmHg} \text { dan nyeri } \\
\text { kepala }\end{array}$ & 11 & 23,4 \\
\hline 2. & $\begin{array}{l}\text { Tekanan darah }>130 \\
\text { mmHg, nyeri kepala, } \\
\text { gangguan penglihatan dan } \\
\text { terjadi oedem }\end{array}$ & 23 & 48,9 \\
\hline 3. & $\begin{array}{l}\text { Tekanan darah }>130 \\
\text { mmHg, nyeri kepala, } \\
\text { gangguan penglihatan dan } \\
\text { terjadi oedem, proteinuria }< \\
3 \text { g/l }\end{array}$ & 13 & 27,7 \\
\hline \multicolumn{2}{|r|}{ Jumlah } & 47 & 100,0 \\
\hline
\end{tabular}

Berdasarkan Tabel 2 dari hasil diagnosa preeklampsia diketahui bahwa paling banyak pada responden tekanan darah $>130 \mathrm{mmHg}$, nyeri 
kepala, gangguan penglihatan dan terjadi oedem sebanyak 23 orang (48,9\%), dan paling sedikit dengan hasil diagnosa tekanan darah $>130$ $\mathrm{mmHg}$, nyeri kepala, gangguan penglihatan dan terjadi oedem, proteinuria $<3 \mathrm{~g} / \mathrm{l}$ sebanyak 13 orang $(27,7 \%)$.

Tabel 3 Distribusi Terapi Dokter pada Ibu Preeklampsiadi Rumah Sakit Santa Elisabeth Batam Tahun 2014

\begin{tabular}{lcc}
\hline \multicolumn{1}{c}{ Terapi dokter } & Jumlah & $\begin{array}{c}\text { Persentase } \\
(\%)\end{array}$ \\
\hline $\begin{array}{l}\text { Istirahat, makanan } \\
\text { rendah garam }\end{array}$ & 12 & 25,5 \\
$\begin{array}{l}\text { Istirahat, makanan } \\
\text { rendah garam, } \\
\text { kunjungan ulang } \\
\text { Bed rest, makanan } \\
\text { rendah lemak dan } \\
\text { garam, minum obat }\end{array}$ & 25 & 21,2 \\
\hline \multicolumn{1}{c}{ Jumlah } & $\mathbf{4 7}$ & $\mathbf{1 0 0 , 0}$ \\
\hline
\end{tabular}

Berdasarkan Tabel 3 diketahui bahwa terapi dokter paling banyak menyarankan istirahat total (bed rest), mengkonsumsi makanan yang rendah lemak dan garam dan mengkonsumsi obat sesuai petunjuk dokter yaitu sebanyak 25 orang $(53,2 \%)$ dan paling sedikit terapi dokter hanya istirahat dan makanan rendah garam sebanyak 12 orang $(25,5 \%)$.

Tabel 4 Distribusi Kunjungan pada Ibu Preeklampsiadi Rumah Sakit Santa Elisabeth Batam Tahun 2014

\begin{tabular}{ccc}
\hline Kunjungan & $\begin{array}{c}\text { Jumlah } \\
\text { (orang) }\end{array}$ & $\begin{array}{c}\text { Persentase } \\
(\%)\end{array}$ \\
\hline I & 25 & 53,2
\end{tabular}

\begin{tabular}{ccc} 
II & 15 & 31,9 \\
III & 7 & 14,9 \\
\hline Jumlah & $\mathbf{4 7}$ & $\mathbf{1 0 0 , 0}$ \\
\hline
\end{tabular}

Berdasarkan Tabel 4 diketahui bahwa ibu preeklampsia melakukan kunjungan ke rumah sakit selama kehamilan trimester III hanya satu kali yaitu 25 orang $(53,2 \%)$ dan paling sedikit yang melakukan kunjungan sebanyak tiga kali yaitu 7 orang $(14,9 \%)$.

Tabel 5 Distribusi Frekuensi Kategori Keberhasilan PenangananPreeklampsia pada Ibu Hamil di Rumah Sakit Santa Elisabeth Batam Tahun 2014

\begin{tabular}{lcc}
\hline $\begin{array}{c}\text { Keberhasilan } \\
\text { Penanganan } \\
\text { Preeklampsia }\end{array}$ & Jumlah & $\begin{array}{c}\text { Persentase } \\
(\boldsymbol{\%})\end{array}$ \\
\hline Berhasil & 21 & 44,7 \\
Tidak berhasil & 26 & 55,3 \\
\hline \multicolumn{1}{c}{ Jumlah } & $\mathbf{4 7}$ & $\mathbf{1 0 0 , 0}$ \\
\hline
\end{tabular}

Hasil distribusi pada Tabel 5 dijelaskan mengenai keberhasilan dalam penanganan preeklampsia pada ibu hamil paling banyak yang tidak berhasil yaitu 26 orang $(55,3 \%)$ dan paling sedikit yang berhasil yaitu 21 orang $(44,7 \%)$.

\section{Tabel 6 Distribusi Frekuensi Hasil Diagnosa Tekanan Darah pada Ibu Hamil di Rumah Sakit Santa Elisabeth Batam Tahun 2014}

\begin{tabular}{ccc}
\hline $\begin{array}{c}\text { Diagnosa Tekanan } \\
\text { Darah }(\mathbf{m m H g})\end{array}$ & Jumlah & $\begin{array}{c}\text { Persentase } \\
(\boldsymbol{\%})\end{array}$ \\
\hline $140 / 90-150 / 100$ & 19 & 59,6 \\
$160 / 100-170 / 110$ & 28 & 40,4 \\
\hline Jumlah & $\mathbf{4 7}$ & $\mathbf{1 0 0 , 0}$ \\
\hline
\end{tabular}


Hasil distribusi pada Tabel 6 dijelaskan mengenai hasil diagnosa tekanan darah pada ibu hamil paling banyak dengan tekanan darah antara $16 / 100-170 / 110 \mathrm{mmHg}$ yaitu 28 orang $(40,4 \%)$ dan paling sedikit tekanan darah pada ibu hamil antara 160/100-170/110 yaitu 28 orang $(40,4 \%)$.

Tabel 7 Distribusi Frekuensi KategoriAntenatal Carepada Ibu Hamildi Rumah Sakit Santa Elisabeth Batam Tahun 2014

\begin{tabular}{lcc}
\hline $\begin{array}{c}\text { Antenatal } \\
\text { Care }\end{array}$ & Jumlah & $\begin{array}{c}\text { Persentase } \\
(\%)\end{array}$ \\
\hline Patuh & 20 & 42,6 \\
Tidak Patuh & 27 & 57,4 \\
\hline Jumlah & $\mathbf{4 7}$ & $\mathbf{1 0 0 , 0}$ \\
\hline
\end{tabular}

Hasil distribusi pada Tabel 7 dijelaskan mengenai antenatal care pada ibu hamil paling banyak dengan kategori tidak patuh yaitu 27 orang $(57,4 \%)$ dan paling sedikit dengan kategori patuh yaitu 20 orang $(42,6 \%)$.

Tabel 8 Distribusi Frekuensi Kategori Kepatuhan dalam Pola Makan pada Ibu Hamil di Rumah Sakit Santa Elisabeth Batam Tahun 2014

\begin{tabular}{ccc}
\hline Pola Makan & Jumlah & $\begin{array}{c}\text { Persentase } \\
(\boldsymbol{\%})\end{array}$ \\
\hline Patuh & 23 & 48,9 \\
Tidak patuh & 24 & 51,1 \\
\hline Jumlah & $\mathbf{4 7}$ & $\mathbf{1 0 0 , 0}$ \\
\hline
\end{tabular}

Hasil distribusi pada Tabel 8 dijelaskan mengenai pola makan ibu hamil paling banyak dengan kategori tidak patuh yaitu 23 orang $(48,9 \%)$ dan paling sedikit dengan kategori patuh yaitu 23 orang $(51,1 \%)$.

Tabel 9 Distribusi Frekuensi Kategori Kepatuhan dalam Istirahat pada Ibu Hamildi Rumah Sakit Santa Elisabeth Batam Tahun 2014

\begin{tabular}{ccc}
\hline Istirahat & Jumlah & $\begin{array}{c}\text { Persentase } \\
(\mathbf{\%})\end{array}$ \\
\hline Patuh & 23 & 48,9 \\
Tidak Patuh & 24 & 51,1 \\
\hline Jumlah & $\mathbf{4 7}$ & $\mathbf{1 0 0 , 0}$ \\
\hline
\end{tabular}

Hasil distribusi pada Tabel 9 dijelaskan mengenai istirahat pada ibu hamil paling banyak dengan kategori tidak patuh yaitu 24 orang $(51,1 \%)$ dan paling sedikit dengan patuh yaitu 23 orang $(48,9 \%)$.

\section{PEMBAHASAN}

\section{Pengaruh Kepatuhan dalam Antenatal Care terhadap Keberhasilan Penanganan Preeklampsia}

Asuhan antenatal penting untuk menjamin agar proses alamiah tetap berjalan normal selama kehamilan. Berdasarkan hasil penelitian diketahui paling banyak ibu hamil tidak mematuhi kunjungan ulang sesuai petunjuk petugas kesehatan. Asuhan antenatal care yang dilakukan ibu hamil dalam kategori tidak patuh yaitu 27 orang $(57,4 \%)$ dan paling sedikit dengan kategori patuh yaitu 20 orang $(42,6 \%)$ disebabkan karena ibu paling banyak bekerja sehingga tidak memiliki waktu untuk memeriksakan kehamilannya ke fasilitas kesehatan, selain itu ibu tidak mengetahui bahwa risiko preeklampsia sering terjadi 
yang pada usia bawah 20 tahun dan di atas 35 tahun juga saat usia kehamilan bertambah juga ibu paling banyak dengan kehamilan pertama kali, sehingga masih belum banyak pengetahuan dan pengalaman yang diketahuinya mengenai kehamilan yang berisiko menyebabkan preeklampsia.

Hasil analisis multivariat diketahui bahwa antenatal care tidak berpengaruh terhadap keberhasilan penanganan preeklampsia dengan nilai $\mathrm{p}$ value $0,076>0,05$, hal ini kemungkinan disebabkan karena kurangnya pengetahuan dan pengalaman ibu dalam mendeteksi kemungkinan komplikasi dalam kehamilan, karena kurangnya melakukan pemeriksaan kehamilan sehingga tidak adanya hubungan rasa percaya ibu hamil dengan petugas kesehatan dalam mendeteksi sedini mungkin upaya pencegahan terjadinya preeklampsia. Hal ini sesuai dengan pendapat Depkes RI (2002) bahwa tujuan utama dari asuhan antenatal adalah untuk mempersiapkan ibu dan bayinya dalam keadaan sehat dengan cara membangun hubungan saling percaya dengan ibu, mendeteksi tanda bahaya yang mengancam jiwa, mempersiapkan kelahiran dan memberikan pendidikan kepada ibu. Hal yang sama juga diungkapkan oleh Destiana (2010) bahwa upaya untuk mencegah preeklampsia/eklampsia di antaranya rajin memeriksakan kandungan (ANC) secara teratur sehingga dapat dideteksi sejak dini ada tidaknya preeklampsia/eklampsia pada ibu hamil. Pemeriksaan pada ibu hamil di antaranya tes urin untuk mendeteksi kemungkinan adanya preeklampsia/eklampsia dan mengukur tekanan darah untuk mendeteksi adanya preeklampsia/eklampsia.

\section{Pengaruh Kepatuhan dalam PolaMakan terhadap Keberhasilan Penanganan Preeklampsia}

Pola makan selama kehamilan sangatlah penting untuk mencegah terjadinya preeklampsia. Berdasarkan hasil penelitian diketahui di saat hamil, pola makan ibu hamil paling banyak dengan kategori tidak patuh yaitu 24 orang $(48,9 \%)$ dan paling sedikit dengan kategori patuh yaitu 23 orang $(51,1 \%)$. Ketidakpatuhan ibu hamil diketahui dari masih mengkonsumsi makanan yang mengandung garam.Ibu hamil tidak mengkonsumsi makanan tinggi protein seperti ikan, Ibu hamil kurang minum air putih sebanyak 8 gelas per hari. Ibu hamil memperbanyak konsumsi sayur berdaun hijau (seperti brokoli, wortel, kacang-kacangan dan buah-buahan). Ibu beranggapan bahwa makanan apa saja baik di konsumsi selama kehamilan, karena janin yang dikandung membutuhkan makanan yang bernilai gizi baik, ibu merasa tidak perlu mengkhawatirkan kenaikan berat badan yang berlebihan di saat hamil. Kurangnya pengaturan pola makan disebabkan ibu yang berlatar belakang pendidikan menengah belum pernah mengetahui pentingnya pengaturan diit selama kehamilan untuk mencegah risiko preeklampsia, meskipun diketahui berat badan ibu tidak berlebih di saat hamil. Ibu kurang mendapat informasi dari 
petugas kesehatan tentang konsumsi garam dan makanan yang berkadar lemak tinggi dapat memicu terjadinya preeklampsia. Hal ini sesuai dengan pendapat Putri (2009) bahwa penting mengatur diit rendah garam, lemak, serta karbohidrat dan tinggi protein, juga menjaga kenaikan berat badan yang berlebihan.

Hasil analisis multivariat dengan uji regresi logistik diketahui pola makan tidak berpengaruh terhadap kejadian preeklampsia dengan nilai $\mathrm{p}(0,631)>0,05$. Hal ini disebabkan karena ibu tidak mengetahui upaya-upaya yang penting dalam penanganan preeklampsia. Ibu menganggap bahwa makanan apa saja dapat di konsumsi selama kehamilan asalkan tidak menimbulkan bahaya pada kesehatan janinnya. Ibu tidak merasa penting melakukan konseling dengan petugas kesehatan untuk mengetahui kondisi kesehatan kehamilannya.Hal ini sesuai dengan pendapat Manuaba (2008) bahwa konseling yang diberikan petugas kesehatan dapat membantu ibu untuk memantau perkembangan dan kesehatan pada masa kehamilan.Informasi yang diberikan petugas kesehatan kepada ibu yang memiliki risiko preeklampsia/ eklampsia dapat melakukan upayaupaya pencegahan dengan melakukan pemeriksaan rutin, menghindari konsumsi makanan yang dapat menimbulkan hipertensi dalam kehamilannya.Hal ini juga sejalan dengan pendapat Indiarti (2009) bahwa pada awal kehamilan tekanan darah ibu hamil yang sudah tinggi, maka ibu hamil harus berhati-hati dengan pola makanannya. Ibu hamil harus mengurangi makanan yang asin dan bergaram seperti ikan asin, ebi, makanan kaleng, maupun makanan olahan lain yang menggunakan garam tinggi.

\section{Pengaruh Kepatuhan dalam Istirahat terhadap Keberhasilan Penanganan Preeklampsia}

Istirahat yang cukup selama kehamilan sangatlah penting dalam menjaga kondisi kesehatan ibu hamil. Berdasarkan hasil penelitian diketahui sehari-hari ibu hamil masih melakukan aktivitas ringan, dan masih sering berjalan kaki. Istirahat yang dilakukan ibu hamil paling banyak dengan kategori tidak patuh yaitu 24 orang $(51,1 \%)$ dan paling sedikit dengan kategori patuh yaitu 23 orang $(48,9 \%)$. Kurangnya istirahat pada ibu hamil disebabkan karena sibuknya ibu hamil dengan pekerjaannya sebagai buruh pabrik dan pembantu harian rumah tangga sehingga ibu hamil tidak lagi memperdulikan kesehatannya di saat hamil, hal ini dilatar belakangi karena tingkat pendapatan keluarga ibu hamil yang mayoritas di bawah UMR, sehingga tidak menghiraukan pentingnya istirahat.

\begin{tabular}{lcr}
\multicolumn{2}{c}{ Hasil analisis multivariat } \\
dengan regresi logistik diketahui \\
bahwa istirahat sangatlah penting
\end{tabular} bahwa istirahat sangatlah penting preeklampsia, hal ini diketahui dengan nilai $\mathrm{p}$ value sebesar $0,002<0,05$. Ini berarti bahwa istirahat sangatlah penting untuk mengurangi terjadinya preeklampsia.Ibu beranggapan bahwa istirahat hanya dilakukan dengan 
berbaring saja, tetapi tidak mengetahui bahwa istirahat dapat juga dilakukan dengan mengurangi pekerjaan seharihari. Hal ini sesuai dengan pendapat Wiknjosastro (2005) bahwa pengetahuan penting diberikan petugas kesehatan pada ibu hamil berupa manfaat istirahat yang berguna dalam pencegahan preeklampsia. Adanya penjelasan bahwa istirahat tidak selalu berarti berbaring, tetapi dapat mengurangi pekerjaan sehari-hari dan dianjurkan lebih banyak duduk dan berbaring.

\section{KESIMPULAN}

Berdasarkan hasil penelitian yang diperoleh maka dapat ditarik kesimpulan sebagai berikut :

1. Ada pengaruh kepatuhan dalam istirahat terhadap keberhasilan penanganan pre- eklampsia.

2. Kepatuhan dalam Antenatal care dan pola makan tidak berpengaruh terhadap keberhasilan penanganan preeklampsia.

\section{SARAN}

1. Bagi Ibu Hamil

Diharapkan agar mengurangi aktivitas rutin dan melakukan aktivitas ringan dalam upaya mencegah terjadinya preeklampsia.

2. Bagi Petugas Kesehatan

Diharapkan kepada petugas kesehatan khususnya bidan selaku penggerak utama bidang kesehatan ibu dan anak, agar membagikan pengetahuan tentang manfaat antenatal care, mengikuti pola makan dan istirahat dalam meningkatkan kesehatan ibu selama kehamilan.

3. Bagi Rumah Sakit

Sebagai bahan masukan bagi pihak rumah sakit agar dapat melakukan penanganan yang tepat bagi ibu hamil yang menderita preeklampsia, agar kejadian preeklampsia ringan dapat dicegah dan preeklampsia berat dapat dikurangi, sehingga dapat meningkatkan kondisi kesehatan ibu selama kehamilan dan memperlancar proses kelahiran.

\section{DAFTAR PUSTAKA}

Amelda, 2009.Gambaran Karakteristik Ibu Hamil dengan Preeklampsia di RSUP H.Adam Malik Batam, Periode 2005-2006. Karya Tulis Ilmiah STIKes Helvetia Batam,

\begin{tabular}{lll} 
y/ht & \multicolumn{3}{c}{ http://www.helvetia.ac.id.librar } \\
tanggal & 5 Juni 2013. &
\end{tabular}

Ammiruddin dkk, 2007.Issu Mutakhir Tentang Komplikasi Kehamilan (Preeklampsi dan Eklampsi), http://www.unhas.ac.id/html/a $\underline{\text { mmir }}$ ud-din/2007.Diakses tanggal $10 \quad$ Oktober 2013.

Anonim, 2009.Preeklampsia dan Eklampsia pada Kehamilan, http://www.blogdokter.net/html $\underline{120}$ 09.Diakses tanggal 18 November 2013. 
Arfian, S. 2002. Perbandingan Indeks Pulsasi Arteri Umbilikalis pada Pre-eklampsia dan Kehamilan Normal. Surabaya: Fakultas Kedokteran Universitas Airlangga, RSUD Dr. Soetomo, http://www.scribd.com/Perban

ding an-Indeks-Pulsasi-ArteriUmbilikus-Pada-Preeklampsia-

dan kehamilan Nor-mal. Diakses tanggal 16 Juni 2013.

Arisman, 2007. Gizi Dalam Daur Kehidupan, Penerbit Buku Kedokteran EGC, Jakarta.

Arikunto, 2006.Produser penelitian Suatu Pendekatan Praktik.Edisi Revisi VI.Jakarta : PT Rineka Cipta.

Ayahbunda, 2008. Mengurangi

Risiko Preeklampsia, Artikel/kehamilan /Tips/tips.menghindari.preekla mpsi a/001/005/400/21/1. Diakses tanggal 5 November 2012.

Ayurai, 2009. Hubungan Antara Usia, Paritas dengan Kejadian Pre eklampsia,http://www.wordpre ss.c om/html/ayurai.Diakses tanggal $15 \quad$ Oktober 2012

Baktiyani, 2005.Perbedaan Efektivitas Pemberian Vitamin E100 IU dengan Aspirin $81 \mathrm{mg}$ Untuk Pencegahan

Preeklamsia Pada Primigravida. JKB.21 : 122.

Bandiyah, 2010. Kehamilan, Persalinan, Gangguan Kehamilan, Penerbit Nuha Medika, Jakarta.
Basso, O. (2001). Higher Risk of Preeclampsia After Change of Partner. An. Effect of Longer Interpregnancy Intervals?. Epidemiology, 12(6): 624-9.

Billington \& Stevenson, 2010. Persalinan, Penerbit Buku Kedokteran EGC, Jakarta.

Bobak, 2004. Buku Ajar Keperawatan Maternitas, Penerbit Buku Kedokteran EGC, Jakarta.

Budiarto, E, 2004. Biostatika untuk Kedokteran dan Kesehatan Masyarakat.Jakarta : EGC.

Campbell DM, MacGillivray I, CarrHill R, Samphier M, 1983. Fetal Sex and Pre-eclampsia in Primigravidae, British Journal of Obstetrics and Gynaecology, 90(1):26-7.

Carpenito, L.J, 2000. Rencana Asuhan dan Pendokumentasian Keperawatan (Edisi 1).Alih Bahasa MonicaEster. Jakarta: EGC.

Champman, 2006.Asuhan Kebidanan Persalinan dan Kelahiran.Jakarta : EGC. Conde-Agudelo A. Belizan JM (2000). Maternal Morbidity and MortalityAssociated with Interpregnancy Interval: Cross Sectional Study. British Medical Journal 321(7271) 1225-1259.

Cuningham, 2001.William Obstetric, 21th.Mcgraw Hill, Medical Publishing Division. 
2006. Obstetri William,

Penerbit Buku Kedokteran

EGC, Jakarta

Curtis, G, 1999. Kehamilan apa Yang Anda Hadapi Minggu per

Minggu. Jakarta : Arcan.

Danim, Sudarman dan Darwis, 2003. Metode Penelitian Kebidanan Prosedur, Kebijakan, dan Etika, Penerbit Buku Kedokteran EGC, Jakarta.

Dinicola dan Dimatteo, 1984. Practioners, Patient and Compliance With Medical Regimens : a Social Physhology Perpective in : handbook of psychological and health, vol 4 : Social Physchology aspects of health

(eds A.Baum, SE Taylor and J.E Singer), Laurence Erbaun Associates, Hillsdale, NJ)

Depkes RI, 2008a. Profil Kesehatan Indonesia 2007, Jakarta.

,2008b.Panduan Pelayanan Antenatal. Jakarta.

,2009.Penilaian K I dan K IV. Jakarta.

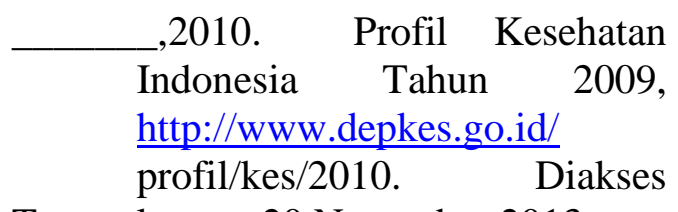

Tanggal 20 November 2013.

Destiana, 2010.Hamil Aman dan Nyaman di Atas 30 Tahun, Penerbit Media Pressindo, Yogyakarta.
Djanah \& Arianti, 2009. Gambaran Epidemiologi Kejadian Preeklamsia/Eklampsia DI RSU PKU Muhammadiyah Yogyakarta Tahun 2007-2009, http://www.jurnal.pdii.lipi.go.i

d. Diakses tanggal 10 November 2013.

Feuer Stein et.al, 1986. Enchanging Reading Comprehension, San Fransisco : Alta Book Centre.

Friedman, 1998. Keperawatan Keluarga: Teori dan Praktik/ Marilyn M. Friedman; alih bahasa, Ina Debora R.L.,Yoakim Asy; Editor, Yasmin Asih, Setiawan, Monica Ester.Ed 3.Penerbit Buku Kedokteran EGC, Jakarta.

Gabit, 1999, Improving Complient by Gabit Ismailov Dunst, 3, http://www.dcc2.bumc.bu.ed/w

orld .TB diperoleh tanggal 8 Februari 2013).

Geoffrey, 1994. Weight Gain in Pregnancy, Fundamental of Obstetrics and Gynecology, 6th edition.

Gunarso, 1990. Psikologis Praktis Anak remaja dan Keluarga, PT BPK. Gunung Mulia, Jakarta.

Haryono, 2006. Upaya Menurunkan Angka Kesakitan dan Kematian

http://www.depkes.go.id/profil/

kes/ ind, diakses tanggal 6 Agustus 2012.Sarwono, Jakarta.http//. www.blogspot.com/html/widya 
wat i/preeklampsia.Diakses tanggal $10 \quad$ Oktober 2013.

Indiarti, 2009.Langsing dan Sehat Setelah Melahirkan Ala Selebritis, Genius Publisher

Yogyakarta.

Kandrawilko, 2009.Kebidanan, Kesehatan, Ibu dan Anak, www:http://

karndrawilko.blogspot.com/sea $\mathrm{rch} /$

label/kesehatan\%20ibu\%20dan

$\% 2$ 0anak.Diakses tanggal 10

Februari 2013.

Kartika, 2001. Faktor-faktor yang Berhubungan dengan Kejadian BBLR di RSUP dr. Hasan Sadikin Bandung, Skripsi Fakultas Kedokteran Universitas Indonesia, http://www.digilib.ui.ac.id.

Diakses tanggal 12 Agustus 2013.

Kompas, 2008. Faktor-faktor yang Mempengaruhi Kepatuhan, Sumber http://cetak.kompas.com/read/x $\mathrm{ml} / 2008 / 03 / 17 / 15105110$.

Diakses tanggal 10 Januari 2013.

Kusmiyati, 2009.Perawatan ibu Hamil (Asuhan Ibu Hamil), Penerbit Fitramaya Yogyakarta.

Llewwllyn, Derek dan Jones, 2002.Dasar-dasar Obstetri dan Ginekologi. Edisi VI. Jakarta : Hipokrates.
Lukman Ali et.al, 2010.Kamus Besar Bahasa Indonesia Edisi Kedua. Balai Pustaka, Jakarta.

Mahfoedz, 2004. Tehnik Membuat Alat Ukur Penelitian, Penerbit Fitramaya, Yogyakarta.

Manuaba, 1998. Ilmu Kebidanan, Penyakit Kandungan dan KB Untuk Pendidikan Bidan, Penerbit Buku Kedokteran EGC, Jakarta.

Mochtar, 2006.Sinopsis Obstetri Jilid II Edisi II, Penerbit Buku Kedokteran EGC, Jakarta.

Musbikin, Imam, 2005. Panduan bagi Ibu Hamil dan Melahirkan. Mitra Pustaka. Yogyakarta.

Notoatmodjo, 2007.Promosi Kesehatan dan Ilmu Perilaku, Cetakan I, Penerbit Rineka Cipta, Jakarta.

Notoatmodjo, 2003. Pendidikan dan Prilaku Kesehatan.Jakarta : PT. Rineka Cipta.

2005.Pendidikan

dan Prilaku Kesehatan.Jakarta : PT. Rineka Cipta.

Putri, 2009. Kenalilah Gejala Pre Eklampsia. Apasih Pre Eklampsia Itu? http://www.chriesaputri.blogspot .com_2009_04_kenalilah-gejalapreeklampsia. html. Diakses tanggal 12 Januari 2013. 
Riduwan 2007.Rumus dan Data dalam Aplikasi Statistika, Penerbit Alfabeta, Bandung.

Prasetyawati, 2012. Buku Saku Gizi \& Kesehatan Reproduksi, Buku Kedokteran Penerbit Buku EGC, Jakarta.

Prawirohardjo, 2008. Ilmu Kebidanan, Penerbit Yayasan Bina Pustaka Jakarta.

Rahayuningsih, 2006.Faktor-faktor yang Mempengaruhi Kejadian Pre-eklampsia, Skripsi Universitas Muhammadiyah Surakarta, http;//www.ums.ac.id.Diakses tanggal 12 Agustus 2013.

Rambulangi, 2005. Beberapa Cara Prediksi Hipertensi falam Kehamilan, Jurnal Cermin Dunia Kedokteran Volume 139 :5 pp 36.http://www.cdk.ac.id. Diakses tanggal 5 Oktober 2013.

Rejeki \& Hayati, 2008. Perilaku Patuh Perawatan Ibu Primigravida dengan Kejadian Preeklampsi Berat di RSUD Soewondo Kendal, Jurnal UniversitasMuhamaddiyahSurak arta.http://www.jurnal.unimus.ac .id/index.php/psn120 12010/article/view/127/108

Rochjati P, 2003. Skrining Antenatal pada Ibu Hamil, Cetakan Pertama, Penerbit Airlangga University Press, Surabaya.
Roeshadi, 2006. Upaya Menurunkan Angka Kesakitan dan Kematian Ibu Pada Penderita Preeklampsi dan Eklampsia, Pidato Pengukuhan Jabatan Guru Besar Tetap dalam Bidang Ilmu Kebidanan dan Penyakit Kandungan, Fakultas Kedokteran Universitas Sumatera Utara, Sumber : http:// http://library.usu.ac.id/download/ e-book/Haryono.pdf. Diakses tanggal 12 Desember 2013.

Royston, 1994. Pencegah Kematian Ibu Hamil, Penerbit Bina Rupa Aksara, Jakarta.

Rozanna.F., R., Dawson, A., Lohsoonthorn, V., \& Williams, M.A. 2009. Risk Factors of Early and Late Onset Preeclampsia among Thai Women, Journal Medical Association

Rozikhan, 2007. Faktor-faktor Risiko Terjadinya Preeklampsia Berat di Rumah Sakit dr. H. Soewondo Kendal, Jurnal Ilmiah Universitas Diponegoro Semarang

Safe motherhood, 2002.Eclamsia Modul Education Material for Teachers of Midwife. Penerbit Buku Kedokteran EGC, Jakarta.

Sarafino, 1990. Health Psychology Biopsychosocial Interaction Singapore : John Willey \& Soes.

Sarwono, 2008. Ilmu Kebidanan. Yayasan Bina Pustaka, Jakarta 
Saifuddin, Abdul Bari, 2001. Buku Acuan National Pelayanan Kesehatan Maternal dan Neonatal.Jakarta : JNPKKRPOGI

$$
\text { 2002.Panduan }
$$

Praktis Pelayanan Kesehatan Maternal dan Neonatal.Jakarta : JNPKKR-POGI.

Senewe P \& Sulistyawati, 2006. Faktor-faktor yang Berhubungan dengan Komplikasi Persalinan Tiga Tahun Terakhir di Indonesia (Analisis Lanjutan SKRT - Sukernas 2001). Buletin Penelitian Kesehatan Volume 32(2) : 83-91.

Sri, 2011.Jumlah Kematian Ibu di Indonesia Masih Tinggi, http:// http://www.muhammadiyah.or.id /id/news-292-detail-jumlahkematian-ibu-di-indonesiamasih-tinggi.html.Diakses tanggal 10 Februari 2013.

Sri Rejeki \& Hayati, 2005.Pengaruh Perawatan Kehamilan Terhadap Terjadinya Pre Eklampsia Berat di RS Dr. Soewondo Kendal, http://

/html/hayati/preeklampsia.Diaks es tanggal 18 Agustus 2013.

Sudigjo, 2008.Dasar-dasar Metodelogi Penelitian Klinis. Penerbit CV. Sagung Seto, Jakarta.

Sunidaya, 2000.Insiden Preeklampsi Eklampsi di RSU Tarakan Kalimantan

Timur,http://www.hanyawanita.c
om/html/sunidaya/insidensi.Diak ses tanggal 20 Oktober 2013.

Suparyanto, 2011. Pre Eklamspia (Keracunan Kehamilan), www.blogspot.com/html/ suparyanto/eklampsia.Diakses tanggal, 12 Oktober 2013.

Taufik, M.2007. Prinsip-Prinsip Promosi Kesehatan dalam Bidang Keperawatan, Untuk Perawat dan Mahsiswa Keperawatan, Cetakan Pertama, Penerbit Infomedika, Jakarta.

Trijatmo Rachimhadhi, 2007. Preeklamsia dan Eklamsia, Jakarta:Yayasan BinaPustaka Sarwono Prawiroharjo. 